Linha D'Água (Online), São Paulo, v. 29, n. 2, p. 195-219, dez. 2016

\title{
AS ESTRATÉGIAS ARGUMENTATIVAS NA AÇÃO DE INDENIZAÇÃO POR DANOS MORAIS: O ESTUDO DE UMA PETIÇÃO INICIAL
}

\author{
ARGUMENTATIVE STRATEGIES IN THE ACTION \\ OF COMPENSATION FOR MORAL DAMAGES: \\ A STUDY OF AN INITIAL PETITION
}

\author{
Ariana de Carvalho* \\ Universidade Federal de Minas Gerais, Belo Horizonte, Minas Gerais, Brasil \\ Mônica Santos de Souza Melo** \\ Universidade Federal de Viçosa, Viçosa, MG, Brasil
}

\begin{abstract}
Resumo: Pautando na Teoria Semiolinguística, pretendeu-se a investigar o discurso desenvolvido em uma petição inicial que envolve ação de indenização por danos morais na relação de consumo, verificando como os recursos das dimensões do logos e do pathos foram empregados pelo advogado para persuadir a juíza de que o pedido de indenização é válido. Objetivou-se também averiguar quais imaginários sociodiscursivos foram expressos nesse discurso. Chegou-se à conclusão de que a noção de contrato de comunicação é muito marcante e norteadora desse discurso. Verificou-se a predominância da dimensão do logos e, ainda, uma regularidade no uso das técnicas dessa dimensão. Averiguou-se que os argumentos de ordem patêmica também tiveram grande importância na argumentação, pois estando o dano moral ligado diretamente ao abalo emocional do requerente pela violação de seus direitos, a argumentação baseada apenas no logos seria pouco consistente. Ficou claro que a voz do advogado é oriunda da coletividade com a qual compartilha valores e princípios.
\end{abstract}

Palavras-chave: Análise do Discurso; Semiolinguística; Argumentação; Petição inicial; Dano Moral.

Abstract: Guided by the semiolinguistics theory, this work intended to investigate initial petition involving a claim for compensation for moral damages in consumer relations, verifying how the dimensions of the features of logos and pathos were used by lawyers to persuade the judge that the claim for compensation was valid. This study also aimed to investigate which socio-discursive imaginaries were expressed in these speeches. We came to the conclusion that the notion of communication contract is very striking and guiding in these speeches. It was also found a predominance of the dimension of logos and a regularity in the use of techniques from this dimension. We also found that the patêmica order arguments also had a great importance in the argumentation, as being the moral damage connected directly to

* Doutoranda do Programa de Pós-Graduação em Estudos Discursivos da Universidade Federal de Minas Gerais - UFMG, Belo Horizonte, Minas Gerais, Brasil; arylet@gmail.com * * Doutora da Universidade Federal de Viçosa - UFV, Viçosa, MG, Brasil; Bolsista do CNPq, processo n. 304833/2014-2; monicamelo@ufv.br 
Linha D'Água (Online), São Paulo, v. 29, n. 2, p. 195-219, dez. 2016

the emotional shock of the applicant for the violation of his rights, the argument based only on the logos would be somewhat consistent. It was clear that the lawyer's voice comes from the collectivity with which he shares values and principles.

Keywords: Rhetoric; The Bakhtin Circle; Speech Genres; Persuasion; Values.

\section{Introdução}

O Direito, inegavelmente, tem grande importância para a sociedade. A multiplicidade de grupos com pensamentos, ideais e posturas diferentes fez com que fosse necessário a proposição de normas que visassem a regulação da vida em sociedade. Reconhecendo a notável ampliação da importância do Direito nos os tempos atuais, muitos pesquisadores da linguagem têm voltado a atenção para os diversos discursos do domínio jurídico, que representam excelentes fontes de dados; esse é o caso da investigação que aqui será exposta.

Esse estudo investigativo tem como objetivo analisar as estratégias argumentativas empregadas em uma petição inicial que envolve ação de indenização por danos morais, observando como o advogado, no papel de sujeito argumentante, desenvolveu seu discurso através dos recursos das dimensões do logos e do pathos. Buscou-se investigar também, a partir disso, os imaginários sociodiscursivos e os valores sociais que são expressos nesse desse tipo de discurso.

A petição inicial é um gênero típico do domínio jurídico responsável por acionar a jurisdição. É através dele que os advogados relatam os fatos que deram origem ao conflito, desenvolvem o fundamento jurídico e expõem o pedido em favor dos seus clientes. Os advogados atuam desenvolvendo uma argumentação consistente para provar a validade do pedido feito ao magistrado e buscar uma resolução satisfatória aos clientes que representam. A petição Inicial selecionada para análise no presente artigo foi obtida no fórum da comarca de Viçosa/ MG e, como de praxe, por questões de éticas, os nomes das partes e do advogado foram suprimidos sendo atribuídos nomes fictícios a eles. 
Linha D'Água (Online), São Paulo, v. 29, n. 2, p. 195-219, dez. 2016

\section{Contextualizando}

O dano moral se consolida quando a dignidade de uma pessoa é atingida, de modo a ser lesada por outrem. Sobre isso, Sarmento tece uma interessante e esclarecedora definição:

dano moral é toda violação à dignidade humana que tenha como consequência sofrimento, exasperação, tristeza, dor. A ilicitude atinge, ainda, todo e qualquer direito da personalidade, provocando lesões à integridade física, intelectual ou moral do indivíduo. (SARMENTO, 2009, p. 24).

Pela citação supracitada entende-se que o prejuízo que a vítima sofre não atinge seu patrimônio material, mas sim, o seu direito de personalidade. Para que um ato ilícito seja configurado como dano moral basta que tenha ocorrido a violação dos direitos de personalidade e que haja a existência de um nexo causal entre o ato de um agente e o sofrimento imposto à vítima (SARMENTO, 2009). Grande importância tem esse conceito, pois, o advogado, ao redigir a petição que abre o processo por dano moral, segue o fio condutor de tentar provar a existência desse nexo causal.

Em se tratando do dano moral nas relação de consumo, que é o foco do presente trabalho, elucida-se que o Código de Defesa do Consumidor elaborou regras próprias para promover e garantir a responsabilidade nas relações de consumo, assegurando ao consumidor o direito à reparação do dano moral. Isso está expresso no Art. 60, inciso VI, um dos mais gerais do referido código: "São direitos básicos do consumidor: a efetiva prevenção e reparação de danos patrimoniais e morais, individuais, coletivos e difusos" (BRASIL, 2011, p. 856).

Segundo Bittar (1999), uma série de ocorrências podem lesar o consumidor e comprometer os direitos personalíssimos dele. Dentre essas ocorrências estão, por exemplo, a cobrança vexatória e a inclusão indevida de nome no SPC. (BITTAR, 1999). Diante disso, uma forma de garantir a proteção dos direitos da personalidade é a própria reparação civil por danos morais. 
Linha D'Água (Online), São Paulo, v. 29, n. 2, p. 195-219, dez. 2016

\section{Referencial teórico}

\subsection{A teoria semiolinguística - uma visão geral}

A Teoria Semiolinguística discute a significação discursiva como resultante de dois componentes: o situacional e o linguístico. Os protagonistas da linguagem são aqueles envolvidos nos processos de produção e interpretação do ato comunicativo: o sujeito destinatário (TUd), o sujeito interpretante (TUi), o sujeito enunciador (EUe) e o sujeito comunicante (EUc).

Um conceito chave que marca a relação entre esses sujeitos é o de contrato de comunicação. Charaudeau (2009, p. 60) define o contrato de comunicação como sendo o "conjunto de restrições que codificam as práticas sociolinguageiras". Essas restrições resultam das condições de produção e interpretação do ato de linguagem e estão condicionadas pelos saberes partilhados pelos interlocutores.

É importante ressaltar que embora haja as restrições, o sujeito age de modo a escolher desenvolver determinadas estratégias durante a troca linguageira, estratégias que fazem parte de seu projeto de fala. (CHARAUDEAU,2006b). A troca linguageira, aquela através da qual um "mundo significado" se torna um objeto de troca com um sujeito destinatário, se realiza com base em quatro princípios fundamentais: princípio de alteridade, princípio de pertinência, princípio de influência e princípio de regulação.

Outro conceito da Semiolinguística que também é norteador do presente trabalho é o de Imaginário Sociodiscursivo. Os imaginários são construções coletivas projetadas pelas representações sociais, estando ligados a

[...] um modo de apreensão do mundo que nasce na mecânica das representações sociais, que, como dissemos, constrói a significação dos objetos do mundo, os fenômenos que são aí produzidos, os seres humanos e seus comportamentos, transformado a realidade em real significante. (CHARAUDEAU, 2007b, p. 53, tradução nossa).

Um imaginário sociodiscursivo se constrói a partir de certo engendramento de saberes do qual se encarrega as representações sociais. Esses saberes são, 
Linha D'Água (Online), São Paulo, v. 29, n. 2, p. 195-219, dez. 2016

segundo Charaudeau (2006a), os saberes de conhecimento e os saberes de crença. Os saberes de conhecimento procuram estabelecer uma verdade sobre o mundo e podem ser subdivididos em saber científico e saber de experiência; os saberes de crença também estão relacionados com os estabelecimento de uma verdade sobre o mundo, mas através de avaliações e julgamentos.

\subsection{A argumentação jurídica}

Em Lógica Jurídica, Perelman (2004) discursou mais detidamente sobre o raciocínio e a argumentação jurídicos. O teórico chama atenção para o fato de o raciocínio jurídico ser marcado por controvérsias, as quais surgem até mesmo nos tribunais mais prestigiosos. Não há como se falar em raciocínio formal em direito, já que as técnicas do raciocínio jurídico devem ser usadas de modo tal que se alcance, de fato, uma decisão socialmente aceitável, ou seja, a lógica do direito é fundamentalmente argumentativa e deve passar pela reflexão de sua função na sociedade.

Um preceito chave da referida obra é considerar que

[...] o sistema jurídico não é um sistema fechado, isolado do contexto cultural e social no qual se insere, pelo contrário, sofre constantemente o seu influxo. [...] Toda nova legislação não faz mais que responder a uma necessidade do meio político, econômico e social. (PERELMAN, 2004, p. 115-116)

Tomando o discurso como dotado de grande vínculo social, não se pode negar que a argumentação no âmbito jurídico deva ser desenvolvida de modo a considerar todo o contexto sociocultural em que ela se insere, para assim, responder à necessidade real dos envolvidos nos processos judiciais.

Seguindo essa linha de pensamento e complementando-a, Perelman explana que "de fato, se nos ativermos ao método positivista, a ideia de uma escolha, de uma decisão, de uma solução razoável, que implique a possibilidade do uso prático da razão, deverá ser excluída." (PERELMAN, 2004, p. 137). Destarte, para o teórico, o silogismo positivista deve ser substituído por uma dialética que se fundamenta mediante a relação da legislação, dos valores sociais e da realidade do momento histórico. 
Linha D'Água (Online), São Paulo, v. 29, n. 2, p. 195-219, dez. 2016

Não é possível encontrar no direito um raciocínio puramente formal no qual não estariam presentes também os juízos de valor a respeitos das situações e até mesmo das decisões e conclusões de impasses. Isso significa afirmar que na efetivação do Direito estão envolvidos também os juízos de valor. Por serem contravertidos, não há um método racional que possibilite determinar um acordo entre eles. $\mathrm{Na}$ ausência de uma lógica específica dos juízos de valor, no caso da existência de opiniões contravertidas recorre-se às técnicas de argumentação. Isso fica esclarecido quando Perelman expõe que "na ausência de técnicas unanimemente admitidas é que se impõe o recurso aos raciocínios dialéticos e retóricos, raciocínios que visam estabelecer um acordo sobre os valores e sobre sua aplicação, quando estes são objeto de uma controvérsia." (PERELMAN, 2004, p. 139).

Reiterando os preceitos da Nova Retórica, Perelman (2004) reforça que toda argumentação pressupõe a adesão do auditório a certas teses e opiniões preliminares. É preciso considerar que os valores e ideias que estão na base das opiniões são elementos culturais, transmitidos pela tradição. $\mathrm{Na}$ argumentação, então, é possível perceber não só a opinião pessoal do sujeito envolvido, mas também elementos de tradição, crenças e outros traços próprios da cultura na qual ele se insere.

\subsection{As dimensões do discurso argumentativo}

Desde Aristóteles as três dimensões do discurso, logos, pathos e ethos são reconhecidas como fundamentais para o desenvolvimento de um discurso persuasivo. Em Arte Retórica e Arte Poética, o filósofo explanou que "entre as provas fornecidas pelo discurso, distinguem-se três espécies: umas residem no caráter moral do orador, outras, nas disposições que se criam no ouvinte; outras no próprio discurso, pelo que ele demonstra ou parece demonstrar.” (ARISTÓTELES, 1998, p. 33).

Assim considerando, a argumentação deve ser pensada em uma perspectiva relacional, pois ela é fruto da relação estabelecida entre essas três dimensões, que embora tenham as especificidades que lhe garantem "vida própria", se interseccionam. Concepção essa que é defendida por Charaudeau:

os argumentos empregados para convencer o outro têm relação tanto com a razão quanto com a paixão, e ainda, com o ethos e o pathos assim como com o logos, já 
que o objetivo do discurso é fazer o outro crer em algo, de modo que este outro está em posição de dever crer (CHARAUDEAU, 2009, p. 281)

Apesar da condição de intersecção que marca a relação entre as três dimensões, é possível ver que os discursos podem ser construídos mais pela presença de uma que de outra. No caso do estudo que aqui se apresenta, o foco de investigação não recairá sobre a dimensão do ethos, a qual concerne ao estudo do caráter moral do orador. Isso porque em se tratando de um advogado, que está na condição de sujeito argumentante, já é presumido que ele disponha de credibilidade e confiança para argumentar dentro do domínio jurídico.

\section{Análise de uma petição inicial ${ }^{1}$}

Iniciando o processo de análise da petição, observa-se que ela possui os três elementos básicos que, segundo Charaudeau (2009), são necessários para que seja desenvolvida uma argumentação:

i- $\quad$ uma proposta sobre o mundo que provoca um questionamento, no caso, a proposta se centra na própria proposição da ação de indenização por danos morais, a qual incita um questionamento quanto à sua legitimidade;

ii- o sujeito argumentante, aquele que se engaja para tentar estabelecer uma verdade quanto à proposta, buscando mostrar que o pedido de indenização por danos morais é legítimo e justificado, ou seja, o advogado;

iii- o alvo da argumentação, a juíza do juizado Especial da Comarca de Viçosa MG). Ela deve ser persuadida de que o pedido de indenização é justificado e que deve, portanto, ser aceito.

1 A análise aqui exposta corresponde a um recorte representativo da dissertação intitulada As estratégias argumentativas em Petição Inicial que envolve ação de indenização por danos morais, apresentada ao Programa de Pós-Graduação em Letras da Universidade Federal de Viçosa, pela estudante Ariana de Carvalho, sob orientação da professora doutora Mônica Santos de Souza Melo (UFV).

CARVALHO, A.; MELO, M. S. S. As estratégias argumentativas na ação de indenização por 
Linha D'Água (Online), São Paulo, v. 29, n. 2, p. 195-219, dez. 2016

Em se tratando da encenação argumentativa (CHARAUDEAU, 2009), averiguou-se que os três componentes do dispositivo argumentativo estão presentes na constituição do discurso da petição. A proposta, ou tese, sustentada pelo argumentante é a de que houve dano moral e que esse dano moral é passível de indenização. Isso é o que ele pretende provar à juíza. A proposição é do tipo "tomada de posição", já que o argumentante demonstra estar de acordo com a proposta, defendendo-a durante todo o texto peticional. Por fim, a persuasão se desenvolve quando o argumentante se engaja em um quadro de raciocínio persuasivo, recorrendo a vários procedimentos para provar que o dano moral ocorreu e que o pedido de indenização tem fundamento.

Os três elementos do dispositivo argumentativo são materializados nas diversas asserções que, em conjunto, formam o texto peticional. Quanto a essas asserções, foi possível verificar ainda, a presença dos elementos de base da relação argumentativa (CHARAUDEAU, 2009). Sobre esses elementos, o teórico discursou que toda relação argumentativa se compõe de pelo menos três elementos: uma asserção de partida (dado, premissa - doravante A1), uma asserção de chegada (conclusão, resultado - doravante A2) e uma ou várias asserções de passagem que permitem passar de uma a outra (inferência, prova, argumento). CHARAUDEAU, 2009). Essas asserções serão identificadas no tópico seguinte.

\subsection{Os elementos de base da relação argumentativa: breve resumo da petição}

Com a finalidade de facilitar a análise dos recursos argumentativos da petição, fazse necessária a apresentação de um resumo identificativo, que será acompanhado da exposição das principais asserções que compõem os elementos de base da relação argumentativa dela. Isso é possível acompanhar abaixo:

\section{Petição 1 (doravante P1) - 16 de maio de 2013}

Ao tentar comprar um jogo de cozinha oferecendo cheques pré-datados para pagá-lo, Carla foi informada de que não poderia finalizar a compra, pois seu nome 
Linha D'Água (Online), São Paulo, v. 29, n. 2, p. 195-219, dez. 2016

constava na lista de negativados. Pesquisando nos órgãos especializados, ela se informou de que a S Telefonia é que havia lançado seu nome no cadastro, o que fez com que ela ficasse surpresa, pois nunca havia estabelecido relação de consumo com tal empresa. Diante disso, pediu à empresa de telefonia que lhe enviasse cópia das contas telefônicas que supostamente ela tinha em atraso, mas a empresa nada enviou e nenhuma justificativa ofereceu. Acionando a jurisdição através de uma ação declaratória de inexistência de dívida $\mathrm{c} / \mathrm{c}$ danos morais $\mathrm{c} / \mathrm{c}$ pedido de antecipação de tutela, Carla pretendeu ter sua situação regularizada, já que devido à restrição de crédito está sofrendo restrições até mesmo em seu trabalho. Ela é, assim, a requerente desse processo e a $\mathrm{S}$ Telefonia, a requerida.

A asserção de partida é:

1-“A Requerente, no início do mês, dirigiu-se até a loja $\mathrm{K}$, nesta cidade, para efetuar a compra de um jogo de cozinha, quando encaminhou-se até o caixa para efetuar o pagamento em parcelas com cheques pré-datados que já haviam sido preenchidos previamente, foi informada que não poderia adquirir o bem desta forma, pois existia restrição ao seu nome junto ao SPC.” (P1, p. 1).

Nessa petição mais de um trecho pode ser considerado como asserção de chegada ou conclusão, pois o advogado pleiteia a favor de seu cliente, além da indenização por danos morais, também a antecipação de tutela. Assim, os trechos abaixo são as asserçôes de chegada:

2-"Sendo assim, requer-se com base em tudo que foi dito, seja a indenização por danos morais fixada em 40 (quarenta salários mínimos, ou o valor que V. Exa. entender ser justo, tendo em vista as reincidências da Requerida.”(P1, p. 6); 3-"Por todo o exposto, requer seja concedida a Tutela Antecipada para determinar a Requerida retire o nome da Requerente junto ao Cadastro de Devedores Inadimplentes do SPC e SERASA [...].”(P1, p. 7, grifos do advogado).

Os seguintes excertos foram os motivos fornecidos pelo advogado para mostrar que de fato ocorreu o dano moral, como se pode verificar nas asserções de passagem expostas a seguir: 
4-"A Requerente ficou com aquilo martelando em sua cabeça e dirigiu-se até a Casa do Empresário quando descobriu que a empresa Requerida havia incluído seu nome no cadastro dos maus pagadores no dia 03/12/2008, devido a pendências referentes ao contrato n. 734308346.” (P1, p. 10);

5-"Neste instante a Requerida [Requerente] ficou mais assustada ainda, pois não havia realizado qualquer transação comercial com aquela entidade. Assim, entrou em contato com a empresa e solicitou que a mesma lhe enviasse cópias das contas telefônicas que estavam em atraso e em seu nome, contudo sua solicitação não foi atendida." (P1, p. 2, grifos nossos);

6-"Indignada com tantos erros da Requerida, a Requerente entrou em contato com ela novamente e argumentou que apesar das faturas estarem em seu nome, não fora ela que requisitou os serviços, já que não possui qualquer vínculo com a prestadora, nunca tendo possuído qualquer relação jurídica com a empresa $\mathrm{Re}$ querida." (P1, p. 2, grifo nosso);

7-"Infrutíferas foram as tentativas de que os débitos fossem cancelados. E assim, por ter tido seu nome negativado tanto junto ao SERASA quanto ao SPC, a Requerente está sofrendo restrições no exercício de seu trabalho, pois ultimamente além de trabalhar junto à UFV, também possui um serviço de bufê que necessita que ela tenha seu CPF liberado.” (P1, p. 2).

\subsection{A dimensão do Logos na petição inicial}

Analisando mais detidamente a petição, observa-se que alguns argumentos de ordem racional aparecem com frequência. Esses argumentos são fundamentais para compor a prova da legitimidade da ação proposta. Em relação às técnicas argumentativas empregadas foi verificado que elas estão interconectadas. Isso significa reconhecer que é a união de tais técnicas que torna válida a argumentação no gênero petição inicial.

Considerando o que foi acima exposto, algumas técnicas argumentativas serão aqui apresentadas em comunhão com outras, haja vista serem de fato complementares. As seguintes técnicas foram identificadas na petição analisada: (I) a Descrição Narrativa, as Ligações de Sucessão, a Acumulação e o Argumento Pragmático; (II) o Dominio de Avaliação do Ético, as Ligações de Coexistência e o Consenso Social; (III) o Argumento de Autoridade, a Citação de Saberes, a Regra da Justiça, o Silogismo Dedutivo e a Definição; (IV) a Repetição, a Composição Vai-e-vem e os Tempos Fortes. 
Linha D'Água (Online), São Paulo, v. 29, n. 2, p. 195-219, dez. 2016

\section{(I) A descrição narrativa, as ligações de sucessão, a acumulação e o argumento pragmático}

Toda petição é constituída através do relato dos fatos jurídicos que deram origem ao processo, sendo a narração desses fatos crucial, já que é através dela que o advogado leva até a juíza o conhecimento da causa. Nota-se, em razão disso, que a técnica da descrição narrativa (CHARAUDEAU, 2009) permeia todo o texto peticional. Relatar para compor a prova, esse é o fundamento do discurso peticional. Como é em meio à narração dos fatos que os argumentos são inseridos, pode-se afirmar que, no gênero petição inicial, a descrição narrativa é a principal técnica argumentativa à qual todas as outras estão atreladas.

Durante toda a petição, o advogado busca fundamentar o pedido de indenização por danos morais, explicitando os motivos que levaram a ele, bem como as consequências das ações dos requeridos para com os requerentes. Logo, devido à natureza desse tipo de discurso e pelo fato de o encadeamento das asserções buscarem fundamentar a causa proposta, há nele um predomínio do modo de encadeamento causa-consequência (CHARAUDEAU, 2009). Conforme tipologia de Perelman e Olbrechts-Tyteca (2005), esse tipo de argumento é do grupo dos argumentos fundados sobre a estrutura do real, mais especificamente do tipo que invoca as ligações de sucessão. As ligações de sucessão se constituem a partir da relação de causa e efeito.

Essa técnica de organizar as asserções, de maneira a evidenciar causa e consequência, pode ser facilmente identificada na divisão asserção de partida, asserções de passagem e asserção de chegada, onde as asserções de passagem inserem os motivos que levaram à grande consequência, ao pedido de indenização por danos morais.

Como se pode notar pelos vários motivos que compõem as asserções de passagem, na petição inicial, mais de um argumento é inserido para compor uma mesma prova. Isso significa que os argumentos do texto peticional são constituídos através do procedimento discursivo da acumulação (CHARAUDEAU, 2009). Discursando sobre a organização dos argumentos no discurso, Perelman (1987, p. 261) explanou que "se vários argumentos chegam a uma mesma conclusão, reforçam-se 
Linha D'Água (Online), São Paulo, v. 29, n. 2, p. 195-219, dez. 2016

mutuamente $[\ldots]$ ”. Destarte, a união de argumentos tem o objetivo de tornar a prova mais consistente.

Com a atividade de relatar e descrever os fatos, verificou-se que o advogado tem o objetivo de mostrar que os atos da requerida são reprováveis principalmente pelas consequências negativas que eles causaram à autora do processo. Assim considerando, a presença do argumento pragmático (PERELMAN; OLBRECHTS-TYTECA 2005) é marcante na petição inicial; esse tipo de argumento é o que "permite apreciar um ato ou um acontecimento em função de suas consequências favoráveis ou desfavoráveis" (PERELMAN; OLBRECHTS-TYTECA, 2005, p. 306).

Quanto ao argumento pragmático é importante ressalvar ainda que embora seja uma categoria do domínio do logos, as consequências relacionadas a ele, no caso das petições iniciais que envolvem dano moral, são de ordem patêmica, sendo o aborrecimento, o constrangimento e a tristeza pelos quais a requerente passou em decorrência dos maus atos da requerida. Isso se explica em razão da própria natureza da petição inicial que envolve dano moral, um tipo de dano, que por atingir os direitos de personalidade, leva a vítima a estados de tristeza e aborrecimento. Explanações sobre os argumentos de ordem patêmica serão desenvolvidas em tópicos posteriores, em um espaço reservado a essa abordagem.

A inserção injusta de nome em cadastro de inadimplentes é a causa do dano moral relatado em P1. Carla teve seu nome inserido no SPC como integrante da lista dos maus pagadores. Os motivos que se integram para provar a ocorrência dos danos morais são: Carla nunca contratou os serviços da requerida; tentou entrar em contato pedindo para ter acesso às suas supostas contas, mas não teve sua solicitação atendida, soma-se a isso o fato de ela, devido a tudo isso, ter sofrido restrições até mesmo no trabalho. A grande consequência desses fatos é a indignação dela e o susto por ter seu nome negativado pela empresa à qual nunca esteve vinculada. Essas consequências fazem com que as ações da empresa requerida sejam mal vistas perante o juizado. $\mathrm{O}$ trecho seguinte é ilustrativo do abalo da requerente:

1-"Indignada com tantos erros da Requerida, a Requerente entrou em contato com ela novamente $[\ldots]$... (P1, p2, grifo nosso).

CARVALHO, A.; MELO, M. S. S. As estratégias argumentativas na ação de indenização por 
Linha D'Água (Online), São Paulo, v. 29, n. 2, p. 195-219, dez. 2016

\section{(II) O domínio de avaliação do ético, as ligações de coexistência e o consenso social}

Na base da construção dos argumentos de P1 foi amplamente empregado o procedimento semântico ${ }^{2}$, pois os argumentos citados para fundamentar a existência do dano moral foram respaldados no domínio de avaliação do que é considerado ético e não ético pela sociedade. O dominio do ético, conforme aponta Charaudeau

define em termos de bem e de mal o que devem ser os comportamentos humanos diante de uma moral externa (as regras de comportamento são impostas ao indivíduo pelas leis do consenso social) ou interna (o indivíduo dá a si mesmo suas próprias regras de comportamento). (CHARAUDEAU, 2009, p. 232).

Nesse sentido, um ponto que merece ser ressaltado é que embora seja o advogado o responsável por apresentar as posturas da requerida, o julgamento delas como reprováveis é pautado em valores e concepções oriundas não do advogado, mas do próprio senso comum. Perelman (2004) discursa sobre a noção de lugar comum que seria "um ponto de vista, um valor que é preciso levar em conta em qualquer discussão e cuja elaboração apropriada redundará uma regra, numa máxima, que o orador utilizará em seu esforço de persuasão.” (PERELMAN, 2004, p. 159). Como mencionado, as posturas da requerida não estão dentro do que a sociedade considera como uma postura ética e o advogado tenta demonstrar isso.

Os valores de uma sociedade influenciam na construção dos argumentos criados a partir dos domínios da avaliação, já que correspondem às normas de um determinado grupo social construídas em cada domínio de avaliação. (CHARAUDEAU, 2009). Destarte, a argumentação desenvolvida pelo advogado se pauta em valores compartilhados por todo o grupo social, grupo do qual ele também faz parte.

Parece fazer parte do projeto de fala do argumentante levar seu alvo, a juíza, a tecer um julgamento negativo da requerida que praticou os atos reprováveis. $\mathrm{Na}$ base de construção dessa estratégia está a noção de Relação de Coexistência

2 De acordo com Charaudeau (2009), os procedimentos semânticos são aqueles que se pautam no uso de argumentos de um consenso social, pelo fato de que os membros de um grupo sociocultural compartilham determinados valores, em certos domínios de avaliação. 
Linha D'Água (Online), São Paulo, v. 29, n. 2, p. 195-219, dez. 2016

(PERELMAN; OLBRECHTS-TYTECA, 2005). Essa noção incute a ideia de que se deve julgar uma pessoa não pelo que ela é, mas por sua relação com os atos por ela praticados; em se tratando do domínio jurídico há que se salientar que "as noções de pessoa e de acto, na sua correlação e na sua independência relativa, são indispensáveis num grande número de argumentações morais e jurídicas." (PERELMAN, 1987, p. 255).

A negligência é apontada como qualificação dos atos da requerida em P1. Segundo o argumentante, o dano moral ocorreu porque

1-“[...] a Requerida agiu com negligência, já que não ousou tomar os devidos cuidados durante a contratação.” (P1, p. 3);

2-“[...] não se olvida que a culpa, consistente na ação negligente da ré (faltando com o dever de cuidado e afrontando o princípio da confiança), está presente e foi devidamente demonstrada nos autos.” (P1, p. 3)

Assim descrevendo, o argumentante deixou explícito o que significou a falta de ética no caso de P1: negligenciar o dever de cuidado e ferir o princípio da confiança. Construiu-se para a requerida a imagem de uma empresa displicente, dissimulada e pouco séria.

\section{(III) Argumento de autoridade, a citação de saberes, a regra da justiça, o silo- gismo dedutivo e a definição}

$\mathrm{Na}$ segunda passagem do texto peticional denominada "Do Direito", o advogado prossegue argumentando para fundamentar o pedido de indenização por danos morais. Essa passagem é marcada por grande exposição de Argumentos de Autoridade (PERELMAN; OLBRECHTS-TYTECA, 2005) e de Citação de Saberes (CHARAUDEAU, 2009). Essas ocorrências se justificam, já que esse é o espaço de que o argumentante dispõe para fundamentar a causa, mostrando que o direito à indenização pleiteado pelo cliente tem respaldo legal.

Como explanado alhures, os argumentos de autoridade e a citação de saberes garantem ao discurso um efeito de autenticidade e credibilidade, tornando a argumentação mais consistente. Isso significa admitir que, em se tratando do domínio 
Linha D'Água (Online), São Paulo, v. 29, n. 2, p. 195-219, dez. 2016

jurídico em que a base está nas leis que visam manter ou recuperar a harmonia no meio social, os argumentos que se fundamentam no que ditam os códigos e artigos de leis são de grande peso para a persuasão.

No gênero petição inicial, a citação de saberes corresponde à citação das leis e artigos de leis. Como a petição selecionada envolve dano moral, especificamente, dano moral nas relações de consumo, as leis e artigos de leis citados são, principalmente, aqueles apregoados pelo Código de Defesa do Consumidor. Muitas menções são feitas também aos preceitos do Código Civil. Os argumentos de autoridade citados, em geral, são aqueles que trazem explanações sobre o que é o dano moral e sobre a garantia de indenização por parte da vítima no caso de sofrer de tal dano.

Esses dois tipos de argumentos foram utilizados em P1, como é possível verificar nos trechos transcritos a seguir:

1- "O código do Consumidor em seu art. 14 determina que:

' fornecedor de serviços responde, independentemente da existência de culpa, pela reparação dos danos causados aos consumidores por defeitos relativos à prestação dos serviços'." (P1, p. 2, grifo do advogado).

2- "Neste sentido, já decidiu a 4a Turma do Superior Tribunal de Justiça, tendo como rel. o Exmo.Sr. Min.César Asfor Rocha, ao julgar o Recurso Especial n. 337771/RJ, em 16/04/2002, decisão publicada no DJ em 19/08/2002, p. 175, verbis:

'Na estipulação do valor do dano moral deve-se observar os limites dos bons princípios e da igualdade que regem as relaçôes de direito, para que não importe em um prêmio indevido ao ofendido, indo muito além da recompensa ao desconforto, ao desagrado, aos efeitos do gravame suportado." (P1, p. 5, grifo do advogado).

Como ilustrado nos excertos acima transcritos, o advogado cita as leis e artigos de leis para mostrar que a requerida infringiu o que estava previsto nas regulamentações. Cita argumentos de autoridade para introduzir informações sobre o dano moral indenizável, isso tudo com o objetivo de possibilitar a verificação, pela juíza, da verossimilhança existente entre os dizeres das autoridades jurídicas e os fatos relatados.

Devido a isso, é recorrente também o emprego da técnica da Definição através da qual o argumentante esclarece conceitos relacionados à noção de dano moral, 
Linha D'Água (Online), São Paulo, v. 29, n. 2, p. 195-219, dez. 2016

bem como o próprio conceito de dano moral. Retomando dizeres de Charaudeau (2009) é importante destacar que a definição é uma interessante estratégia de persuasão, porque ela produz efeito de evidência de saber e conhecimento.

Fazendo referência à responsabilidade objetiva que envolve a prática de danos aos consumidores pelos prestadores de serviço, o argumentante de P1 definiu, de forma breve, o que seria um caso que configura responsabilidade objetiva. Essa definição foi inserida para esclarecer que o caso evidenciado no processo envolve esse tipo de responsabilização. O trecho que traz essa definição é o seguinte:

1-“Essa modalidade de responsabilidade tem lugar, conforme a doutrina de Celso Antônio Bandeira de Melo, quando a ação for omissiva [...]” ( P1, p. 3)

Ao inserir argumentos de autoridade e citar as leis que esclarecem sobre o dano moral e o direito da vítima à indenização compensatória, o argumentante parece objetivar que seja reconhecida, pelo juizado, a verossimilhança entre os fatos dos processos e o que dita a teoria, para que assim, o caso possa ser de fato julgado como legítimo caso de dano moral e o pedido de indenização da requerente seja legitimado. O processo de identificação entre fatos e teoria ocorre através de dedução por silogismo (CHARAUDEAU, 2009). Observa-se, destarte, que o silogismo é marcante principalmente na passagem "Do Direito" em que o advogado expõe os artigos de lei, as citações da jurisprudência e argumentos de autoridade para que seja formada a prova de que houve o dano moral e de que a busca por indenização é válida.

$\mathrm{Na}$ petição inicial, a conclusão que fecha o silogismo muitas vezes é materializada através de uma ou mais asserções inseridas no texto; outras vezes, a conclusão fica somente no plano do raciocínio lógico. Abaixo foi transcrita a asserção que figura como conclusão do silogismo desenvolvido pelo advogado de P1:

1-“Não resta dúvida quanto a negativação do nome do Requerente, tem-se, portanto, como devidamente configurado o dano moral [...]” (P1, p. 5).

Para compreender o silogismo que sustenta essa conclusão é preciso estar ciente dos demais trechos de P1 que foram anteriormente citados. 
Linha D'Água (Online), São Paulo, v. 29, n. 2, p. 195-219, dez. 2016

Além da presença do silogismo dedutivo, observa-se que a regra da justiça também é uma constante nesse texto. Baseando-se no princípio da identidade, pela regra da justiça, um tratamento igual deve ser dado a situações semelhantes (PERELMAN; OLBRECHTS-TYTECA, 2005). Assim, é notável que, no gênero petição, a existência do precedente tem grande valor para julgar os casos que surgiram posteriormente.

Uma atenção especial deve ser dada à técnica da regra da justiça, que predomina no âmbito jurídico, pois como o Direito tem a função de regular a vida em sociedade, pautando essa regulação no princípio da equidade, os casos semelhantes devem de fato ser tratados de forma análoga para que não se veja surgir um Direito que acirre os litígios ao invés de buscar soluções razoáveis para eles. Logo, a regra da justiça está presente na petição, pois ela "fornecerá o fundamento que permite passar de casos anteriores para casos futuros." (PERELMAN; OLBRECHTS -TYTECA 2005, p. 248).

A existência de um precedente e a menção a ele no texto funcionam como um bom recurso argumentativo, visto que endossam a argumentação. Se um caso anterior foi julgado procedente e a causa foi ganha pelo requerente, há maiores chances de que o novo caso que se assemelha ao anterior, também alcance êxito.

Em P1 foi observada a existência de trechos em que o argumentante retomou casos já julgados e que se mostraram semelhantes ao fato jurídico da ação que ele estava a pleitear. No trecho exemplificativo a seguir nota-se o precedente sendo empregado como recurso argumentativo:

1-“A questão já é pacífica e, por isso, prescinde de maiores elucubrações, se não vejamos:

'EMENTA: INDENIZAÇÃO - DANO MORAL - SERVIÇO DE TELEFONIA - INSTALAÇÃO DE TERMINAL TELEFÕNICO SEM CONSENTIMENTO DO TITULAR - FALTA DE COMPROVAÇÃO DA CHECAGEM DA VERACIDADE DA SOLICITAÇÃO - CONDUTA NEGLIGENTE - INSCRIÇÃO INDEVIDA CADASTRO DE PROTEÇÃO AO CRÉDITO - DEVER DE INDENIZAR - QUANTUM INDENIZATÓRIO - CRITÉRIOS - RAZOABILIDADE - PROPORCIONALIDADE - FUNÇÃO DIDÁTICA E REPARADORA. A concessionária de serviços públicos, que não agiu com o esperado dever de cuidado ao autorizar a instalação

CARVALHO, A.; MELO, M. S. S. As estratégias argumentativas na ação de indenização por 
Linha D'Água (Online), São Paulo, v. 29, n. 2, p. 195-219, dez. 2016

de linha telefônica, não comprovando a checagem da veracidade da solicitação, pratica conduta negligente, da qual resulta a obrigação de indenizar [...] (TJMG, AP. Cível n. 10024.04.531012-5/001(1). AFRÃNIO VILELA. Publ.20/04;2006)” (P1, p. 6, grifo do advogado).

\section{(IV) Repetição, a composição vai-e-vem e os tempos fortes}

Segundo ressaltou Perelman (1987), prolongar a atenção a um elemento garante a ele presença no discurso e isso tem efeitos na argumentação, já que a presença acaba por atuar na sensibilidade do auditório. Na petição, um recurso responsável por isso é a repetição que é usada com grande recorrência. Infere-se que repetindo determinadas passagens, o advogado objetiva fazer com que o alvo da argumentação direcione sua atenção para o elemento repetido. Esse elemento, por ganhar presença no discurso, acaba se tornando o centro da argumentação.

A repetição se desenvolve através do procedimento de composição do tipo vai-e-vem, uma vez que para enunciar novas informações sobre os fatos da ação, o argumentante retoma informações já expressas e, assim, cria presença para elas.

Observa-se que aliado à repetição está outro recurso responsável por criar presença no discurso peticional, que é a marcação dos tempos fortes (CHARAUDEAU, 2009). Pela análise das expressões e trechos destacados através do negrito ou do sublinhado foi verificado que o argumentante destaca o que julga ser de fundamental importância para a resolução do processo, pretendendo, destarte, que a juíza observe essas informações com mais cuidado e atenção.

$\mathrm{O}$ argumentante de $\mathrm{P} 1$ reitera algumas vezes que o caso narrado envolve responsabilidade objetiva, ou seja, que a empresa ré irá responder por danos morais independentemente da existência de culpa. Retomando essa informação, ele pretende mostrar que, independentemente do que levou à negativação injusta do nome da requerente, a S Telefonia terá que arcar com a indenização. São os seguintes excertos ilustrativos disso:

1-"No caso sub judice, a despeito de ser objetiva sua responsabilidade, a /requerida agiu com negligência [...]” (P1, p. 2-3, grifo nosso);

CARVALHO, A.; MELO, M. S. S. As estratégias argumentativas na ação de indenização por 
Linha D'Água (Online), São Paulo, v. 29, n. 2, p. 195-219, dez. 2016

2-"A despeito do que preceitua o Código de Defesa do Consumidor, a responsabilidade objetiva da Requerida decorre também do fato de a mesma ser concessionária de serviço público federal [...]” (P1, p. 3, grifo nosso);

3-"No caso em tela, o fato de um terceiro ter lançado mão dos documentos e informações pessoais da Requerente para solicitar instalação de terminal telefônico, em nada minimiza o dever da requerida de indenizar, já que a responsabilidade do fornecedor de serviços é objetiva [...]” (P1, p. 3, grifo nosso).

\subsection{A dimensão do Pathos na petição inicial}

Uma análise mais apurada permitiu perceber que as estratégias de patemização também estão muito presentes no texto peticional, funcionando como forte aliada da dimensão do logos na atividade de persuadir.

Aplicando ao contexto desse estudo investigativo, há que se salientar que o dispositivo de comunicação jurídico não é muito predisposto ao surgimento do efeito patêmico, já que são os saberes normativo e científico a base dos discursos jurídicos e isso dá a eles uma forte orientação racionalizante. Entretanto, a natureza da ação materializada na petição, isto é, o fato de a ação envolver dano moral garante espaço às estratégias de patemização.

Averiguou-se que em P1 a representação patêmica foi configurada através de duas etapas, o que evidencia que o advogado desenvolveu uma mise en sciène discursiva com visada petemizante: a. descrição das açôes da requerida e da própria requerida através de qualificações negativas que a reprovam e $b$. descrições do estado emocional e psicológico da requerente diante das situaçôes problemáticas vivenciadas.

\section{a. A requerida como causadora de danos: a qualificação negativa}

Na petição, por diversas vezes, o argumentante descreveu a requerida como uma instituição negligente, omissa e a responsabilizou pelos danos causados à requerente. Tais colocações têm a finalidade de levar o interpretante a desenvolver um julgamento negativo da requerida e, por conseguinte, a avaliar a requerente como vítima das artimanhas de uma empresa mal intencionada. No trecho abaixo é possível visualizar as descrições que responsabilizam a requerida: 
Linha D'Água (Online), São Paulo, v. 29, n. 2, p. 195-219, dez. 2016

1-“[...] a Requerida agiu com negligência, já que não ousou tomar os devidos cuidados durante a contratação [...]” (P1, p 3, grifo nosso);

Assim, foi observado que o advogado atuou discursivamente responsabilizando a requerida pelos prejuízos causados à requerente. No outro polo criado pelas descrições do advogado está a requerente que seria representada como uma pessoa do bem, cidadã honesta e cumpridora dos seus deveres e obrigações, verdadeira vítima da requerida. Essa oposição criada serve como meio estratégico para que os atos da requerida sejam vistos como ainda mais reprováveis, visto que lesaram pessoa idônea.

\section{b. Os transtornos emocionais da requerente}

Descrevendo os transtornos pelos quais a requerente passou devido às ações da requerida, o advogado tenta comover a juíza. Ele parece querer tocá-la objetivando que ela desenvolva uma espécie de compaixão por aquele ser que foi lesado e, assim, pronuncie uma decisão favorável a ele. A compaixão, segundo a visão aristotélica, é sentida quando "há certo pesar por um mal que se mostra destrutivo ou penoso, e atinge quem não o merece [...].” (ARISTÓTELES, 2000, p. 53).

É preciso salientar que as representações patêmicas estão relacionadas à descrição das situações a partir de certo julgamento de valor que é compartilhado pela coletividade (CHARAUDEAU, 2007a). Corroborando essa concepção, afirma-se que a juíza só poderia sentir compaixão pela vítima considerando que ela se insere em uma coletividade, a qual julgaria ações a exemplo das praticadas pela requerida como ações reprováveis e dignas de punição. É nessa relação entre emoção e saberes de crença que o advogado se baseia ao elaborar o projeto de fala que visa conquistar a adesão da juíza. Nota-se que o domínio de avaliação do ético também tem sua influência na emoção, pois é devido ao fato de as ações da requerida serem tão antiéticas, na visão da coletividade, que um membro dessa mesma coletividade poderia chegar a sentir compaixão pela vítima. Os seguintes trechos são representativos dos abalos emocionais sofridos pela requerente: 
Linha D'Água (Online), São Paulo, v. 29, n. 2, p. 195-219, dez. 2016

1-"Neste instante a Requerida ficou mais assustada ainda, pois não havia realizado qualquer transação comercial com aquela entidade [...].” (P1, p. 2, grifo nosso); 2-“[...] E assim, por ter tido seu nome negativado junto ao SERASA quanto no $\mathrm{SPC}$, a Requerente está sofrendo restriçóes no exercício de seu trabalbo [...].” (P1, p. 2, grifo nosso).

\subsection{Os valores e os imaginários sóciodiscursivos}

Retomando os preceitos de Charaudeau (2006a), salienta-se que através da análise dos diversos discursos que circulam na sociedade é possível verificar os imaginários sociodiscursivos, as construções coletivas que são projetadas nas múltiplas representações sociais constituídas nesses discursos. No discurso peticional foi possível verificar quais valores e concepções são compartilhados pela sociedade na qual ele circula. Esses valores seriam os imaginários sociodiscursivos que emanam nos discursos:

\section{a- A noção de tempo como elemento valioso}

Discutindo sobre as metáforas constituídas no seio social, Lakoff e Johnson (2002) enfatizaram que na nossa cultura o tempo é visto como algo valioso e limitado, algo que se pode ganhar, perder, gastar ou poupar. $\mathrm{O}$ mundo capitalista tende a marcar o trabalho associando-o ao tempo. Assim, uma pessoa recebe de acordo com o seu tempo de prestação de serviço, sendo o pagamento por hora, mês ou ano. Desse panorama emana a metáfora que relaciona tempo e dinheiro. É bastante comum, então, que surjam frases como "eu gastei muito tempo nesse trabalho", "ele não costuma perder tempo".

Seguindo essa concepção compartilhada pela coletividade, o tempo também apareceu como algo de grande importância em P1. Diversos trechos fizeram menção ao tempo, esclarecendo que a requerente teve que "gastar" do tempo dela para tentar resolver os conflitos com a requerida. A perda de tempo e o grande esforço na tentativa de resolução dos conflitos foram expostos como fatores que geraram grande transtorno à requerente, logo, fatores que deram azo à ocorrência do dano moral. A requerente Carla teve muito transtorno ao entrar em contato várias vezes com a S Telefonia na tentativa de solucionar os problemas e ter seu nome retirado 
Linha D'Água (Online), São Paulo, v. 29, n. 2, p. 195-219, dez. 2016

do cadastro de inadimplentes. Nos contatos estabelecidos com a empresa ré, Carla despendeu muito de seu tempo tentando ter seus direitos assegurados. Isso é o que se pode inferir das exposições do advogado nos trechos abaixo:

1-“[...] a Requerente entrou em contato com ela novamente e argumentou que apesar das faturas estarem em seu nome, não fora ela que requisitou os serviços [...].”(P1, p. 2);

2-"Infrutíferas foram as tentativas de que os débitos fossem cancelados [...]." (P1, p. 2).

A análise dos trechos destacados acima permite chegar à conclusão de que o dano moral está diretamente ligado ao tempo despendido pelos requerentes, nos esforços que esses fazem para tentar a resolução do conflito.

\section{b- O contrato como obrigação}

A relevância do contrato é incontestável, principalmente quando se considera a era atual em que a globalização integrou ainda mais as pessoas, fazendo surgir diferentes relações entre elas. Todas as relações estabelecidas dentro do espaço social estão sujeitas a um contrato, já que é preciso regras para estabelecer e manter a harmonia entre os diferentes grupos sociais que se relacionam. A partir dessa observação, pode-se afirmar que o contrato é muito mais que um simples pacto, ele é uma obrigação. Borges (2005) ressalta que além de estar sujeito ao Direito das Obrigações, o contrato também encontra espaço na Parte Geral do Código Civil, e esclarece que "na disciplina dos fatos jurídicos encontra-se a teoria geral do negócio jurídico, cuja maior expressão é o contrato.” (BORGES, 2005, p. 1).

O discurso esclarecedor de Borges (2005) serve para confirmar que o contrato de fato ocupa um espaço central na sociedade. Isso é provado quando se considera que ele aparece já na parte inicial do Código Civil, o qual é responsável por apregoar as leis que regem a vida de todo cidadão desde seu nascimento até sua morte. Desse modo, a visão do contrato como obrigação e elemento central de todas as relações sociais é uma concepção compartilhada pela coletividade. Essa 
Linha D'Água (Online), São Paulo, v. 29, n. 2, p. 195-219, dez. 2016

concepção pode aparecer nos diversos discursos que permeiam a sociedade, em especial naqueles inseridos e oriundos do domínio jurídico.

Seguindo o que foi acima exposto, averiguou-se que em P1 o contrato figura como a base das relações entre consumidor e prestador de serviços. A concepção que se deixa transparecer através do discurso peticional é que ao assinar um contrato, um consumidor não está apenas fazendo um acordo, mas ele está, principalmente, confiando no que foi estabelecido com o outro e, acima de tudo, confiando nesse outro. Quebrar um contrato é quebrar o princípio da boa-fé que deve reger toda relação comercial, é ir de encontro a algo que tem proteção jurídica. Em P1, o raciocínio de que não se pode negativar o nome de uma pessoa com a qual não se estabeleceu relação contratual foi bem explicitado:

1-“[...] não podendo a Requerente ser cobrado e inscrito no SPC e SERASA como inadimplente do preço de um serviço que nunca contratou e sequer recebeu.” (P1, p. 2).

Essa análise serviu para elucidar o quanto as construções coletivas mais típicas estão refletidas também nos discursos jurídicos, sustentando a argumentação do advogado juntamente com as leis e artigos de leis citados.

\section{Conclusão}

Esse estudo investigativo contribuiu para confirmar, que embora o domínio jurídico esteja imerso em uma racionalidade que lhe é peculiar, a dimensão patêmica tem também grande espaço na argumentação desenvolvida dentro de alguns gêneros pertencentes a esse domínio. Não se pode apurar qual estratégia causou mais efeito na juíza, se a de ordem racional ou patêmica. $\mathrm{Na}$ verdade, nem se pode afirmar que causou efeito, pois é possível ter controle sobre os efeitos visados, mas não sobre os efeitos produzidos. Mas pode-se inferir, e isso também é fruto de processo interpretativo, que os argumentos das duas dimensões se complementaram e que a ausência de uma delas no discurso acarretaria uma argumentação pouco consistente.

É notório e, também digno de comentário, que os discursos peticionais estão tão apoiados no que ditam as leis quanto nos diversos valores que permeiam toda 
Linha D'Água (Online), São Paulo, v. 29, n. 2, p. 195-219, dez. 2016

a sociedade na qual eles se inserem. A voz do advogado é oriunda da coletividade com a qual compartilha valores e princípios. $\mathrm{O}$ advogado, por fazer parte dessa mesma sociedade, é influenciado por tais valores e deixa com que eles transpareçam em seu discurso.

\section{Referências}

ARISTÓTELES. Arte retórica e arte poética. São Paulo: Ediouro, 1998.

Retórica das paixões. Tradução de Isis B. B. da Fonseca. São Paulo: Martins Fontes, 2000.

BITTAR, Eduardo Carlos Bianca. Direitos do consumidor e direitos de personalidade: limites, intersecções, relações. Revista de informação legislativa. V. 36, n 143, p. 63-69, jul/set. 1999. Disponível em: http://www2.senado.gov.br/bdsf/item/id/504. Acesso em: 12 abr. 2013.

BORGES, Roxana Cardoso Brasileiro. A atual teoria geral dos contratos. Jus navigandi, n. 811, 22 set. 2005. Disponível em: <http://jus.com.br/artigos/7267>.Acesso em: 18 fev. 2014.

BRASIL. Código de defesa do consumidor. In: Vade mecum Saraiva. 11ª ed. São Paulo: Saraiva, 2011.

CHARAUDEAU, Patrick. Discurso politico. Tradução Fabiana Komesu e Dilson Ferreira da Cruz. São Paulo: Contexto, 2006a.

. Discurso das midias. São Paulo: Contexto, 2006b.

. A patemização na televisão como estratégia de autenticidade. In: MENDES, E.; MACHADO, I. L. (orgs.), As emoçôes no discurso, Mercado Letras, Campinas: Mercado Letras, 2007a, p. 23-56.

Les stéréotypes, c'est bien. Les imaginaires, c'est mieux. Le site de Patrick Charaudeau, 2007b. Disponível em: <http://www.patrick-charaudeau.com/La-argumentacion-persuasiva〉. Acesso em: 10 abr. 2013.

Linguagem e discurso: modos de organização. São Paulo: Contexto, 2009.

CARVALHO, A.; MELO, M. S. S. As estratégias argumentativas na ação de indenização por 
Linha D'Água (Online), São Paulo, v. 29, n. 2, p. 195-219, dez. 2016

LAKOFF, George; JOHNSON, Mark. Metáforas da vida cotidiana. São Paulo: Mercado das Letras, 2002.

PERELMAN, Chaïm. Argumentação. Einaudi: oral/escrito, argumentação. Lisboa, Imprensa Nacional/Casa da Moeda, v.11, p. 234-265, 1987.

Lógica jurídica: nova retórica. São Paulo: Martins Fontes, 2004.

PERELMAN, Chaïm; OBRECHTS-TYTECA, Lucie. O tratado da argumentação: a nova retórica. 2 ed. Trad. Maria E. de Almeida P. Galvão. São Paulo: Martins Fontes, 2005.

SARMENTO, George. Danos morais. São Paulo: Saraiva, 2009.

Recebido: 28/08/2016.

Aprovado: 18/09/2016.

CARVALHO, A.; MELO, M. S. S. As estratágias argumentativas na ação de indenização por 